\title{
Service Quality and Customer Satisfaction: Evidence of Nepalese Banks
}

\author{
Dr. Prakash Shrestha \\ Lecturer, Nepal Commerce Campus
}

\begin{abstract}
Present research has been conducted to examine the customer satisfaction on service quality of selected commercial banks of Nepal. The study has employed descriptive research design and quantitative study by using survey methodology to deal with customer satisfaction in the context of Nepalese commercial banks. In this study, the data collected through questionnaire from 65 respondents (out of 100 customers of commercial banks) has been used for analysis. A detail study has been done on the basis of five dimensions as suggested by Parasuraman, Zeithamal and Berry (1988). They are reliability, responsiveness, assurance, empathy and tangibles. The result of the study indicated that the overall customers are satisfied with service quality of the commercial banks. Hence the level of customer satisfaction of the commercial banks on the basis of service quality can be considered satisfactory.
\end{abstract}

Keywords: Service quality, Customer satisfaction, Reliability, Responsiveness, Assurance, Empathy, Tangibles, Commercial Banks.

\section{Introduction}

Customers are king in business. Their satisfaction is important for success of the business. Customer satisfaction is an important element of banking strategy in today's increasingly competitive environment. Bank management must identify quality dimensions and improve service quality to satisfy customers. The banking industry is highly competitive, with banks not only competing among each other; but also with non-banks and other financial institutions (Kaynak \& Kucukemiroglu, 1992; Hull, 2002). Most bank product developments are easy to duplicate and when banks provide nearly identical services, they can only distinguish themselves on the basis of price and quality. Therefore, customer satisfaction is potentially an effective tool that banks can use to gain a strategic advantage and survive in today's ever-increasing banking competitive environment.

In today's competitive business environment, the commercial banks are competing with others in order to become the best banks and have maximum deposits and gain trust of customers in Nepal. In this case the customer satisfaction, loyalty and 
retention become the major issues. The major factors that attract the customers today is high interest rates and fast as well as quality services. The banks that provide high quality service retain the existing customer and also pull the new customers towards their offices and branches. Therefore, banks launch new schemes and provide various quality services and facilities so as to retain and attract customers with different characteristics and businesses. Hence, this study explores service quality as a means for customer satisfaction.

Service quality has become ever more important to the achievement of customer satisfaction and competitive advantage and coupled with the increasing complexities of the need and expectation of customers, it is imperative to explore the relationship between service quality and customer satisfaction. So, the major objective of this study is to examine the level of customer satisfaction on the basis of service provided by the commercial banks in Nepal. The specific objectives are: to analyze the problems rose by the customers and are solved by the banks; to analyze the fulfillment of promises and services made by the banks and to identify how often the banks inform about their various products and services in Nepal. The study shows that customer satisfaction is determined by the service quality provided by the selected commercial banks.

\section{Literature Review}

\section{Customer Satisfaction}

Customer satisfaction is one of the important aspects of this research. It refers to serving people with their requirements and making them satisfy. It is a person's feeling of pleasure of or disappointment resulting from comparing a product's, perceived performance in relation to his or her expectations. If the performance falls short of expectations, the customer is dissatisfied. If the performance matches the expectations, the customer is satisfied. If the performance exceeds the expectations, the customer highly satisfied or delighted (Kotler \& Keller, 2012). So customer satisfaction refers to the extent to which customers are happy with the products and services provided by a business. Customer satisfaction level can be measured using survey techniques and questionnaire. Gaining high level of customer satisfaction is very important to a business because satisfied customer are most likely to be loyal and to make repeated orders and to use a wide range of services offered by a business.

Customer satisfaction has been gaining increasing attention from the researchers and practitioners as a recognized field of scholarly study and is a fundamental tool used by financial institutions for enhancing customer loyalty and ultimately organizational performance and profitability (Faizan, et al., 2011). In businesses where the underlying products have become commodity- like, quality of service depends heavily on the quality of its personnel. This is well documented in a study Leeds (1992). He documented that approximately 40 percent of customers' switched banks because of what they considered to be poor service. Leeds further argued that nearly three-quarters of the banking customers mentioned teller courtesy as a prime consideration in choosing a bank. The study also showed that increased use of service quality and professional behaviours (such as formal greeting) improved customer satisfaction and reduced customer attrition. Additionally, satisfied customers may look for other providers 
because they believe they might receive better service elsewhere. However, keeping customers is also dependent on a number of other factors. These include a wider range of product choices, greater convenience, better prices, and enhanced income (Storbacka, et al, 1994). Formell (1992) in his study of Swedish consumers notes that although customer satisfaction and quality appear to be important for all firms, satisfaction is more important for loyalty in industries such as banks, insurance, mail order and automobiles.

In one research, Ioanna (2002) further proposed that product differentiation is impossible in a competitive environment like the banking industry. Banks everywhere are delivering the same products. For example, there is usually only minimal variation in interest rates charged or the range of products available to customers. Bank prices are fixed and driven by the market price. Thus, banks management tends to differentiate their firm from competitors through service quality. Service quality is an imperative element impacting customers' satisfaction level in the banking industry. In banking, quality is a multi-variable concept, which includes differing types of convenience, reliability, services portfolio, and critically, the staff delivering the service.

\section{Service Quality}

Service quality is another important aspect of this research. The attainment of quality in product and services has become a crucial concern of the 1980s. While quality in tangible goods has been described and measured by marketers, quality in services is largely undefined and unresearched. Parasuraman, Zeithaml and Berry (1988) attempt to rectify this situation by investigating the quality in different service businesses and by developing a model of service.

Service quality has been described as a form of attitude that results from the comparison of expectation with performance (Cronin \& Taylor, 1992: Parasuraman et al., 1985). Gronroos (1982) argued that customers, while evaluating the quality of a service, compare the service they expect with perceptions of the services they actually receive. It has been argued that the quality of services is not a one-dimensional that relate to both core and augmented service offerings (Bitran \& Lojo, 1993; Gronroos, 1984; Lewis 1993). Customer satisfaction can thus be based not only on the judgment of the customer towards reliability of the delivered service but also on customer's experiences with the service delivery process. It is generally accepted that customer satisfaction often depends on the quality of product or service offering (Anderson \& Sullivan, 1993; Levesque \& McDougall, 1996). For this reason, research on customer satisfaction is often closely associated with the measurement of quality. Thus, both service quality and customer satisfaction share a close relationship.

\section{Service Quality Dimensions}

In banking industry, service quality is perhaps the most critical aspect of the customer experience. Accordingly organizations regularly monitor service quality and satisfaction in their quest to improve customer retention. Service quality is based on the notion that service quality can be measured by comparing customer expectations against the service received. The gap between expectation and actual 
service is measured along key service dimensions. It involves measuring both customer perceptions and expectations of service along key service quality dimensions. Examining differences between the desired level of service and the actually delivered reveals where improvements in the service mix are required. Originally, Parasuraman (1985) identify the 10 core components of service quality as reliability (consistence performance and dependability), responsiveness (willingness/readiness to serve), competence (possessing knowledge and skills), access (approachability and ease of contact), courtesy (politeness, consideration and friendliness of staff), communication (updating and listening to customers), credibility (trustworthy and reputable, with customer interests at heart), security (freedom from danger and risk), customer knowledge (understanding needs and personalized attention), as well as tangibles (facilities and physical features).

In subsequent research (Parasuraman, Zeithaml \& Berry, 1988) the service quality dimensions are categorized into five categories tangibles, reliability, responsiveness, assurance and empathy. They are defined as follows:

a. Reliability: It refers to the dependability of the service providers and their ability to keep their promises. In other words, it means that the company delivers on its promises, service provision, problem resolution and pricing. Customers want to do business with companies that keep their promises, particularly their promises about the service outcomes and core service attributes.

b. Responsiveness: It refers to the reaction time of the service. It is willingness to help customers and to provide prompt service. This dimension emphasizes attentiveness and promptness in dealing with customer requests, questions, complaints and problems. It is communicated to customers by the length of time they have to wait for assistance, answers to questions, attentions to problems etc. It also captures the notion of flexibility and ability to customize the service to customer needs.

c. Assurance: It refers to the level of certainty a customer has regarding the quality of the service provided. It is defined as employee's knowledge and courtesy and the ability of the firm and its employees to inspire trust and confidence.

d. Empathy: It is when a service employee shows that s/he understands and sympathizes with the customer's situation. The greater the level of this understanding, the better. Some situations require more empathy than others. It is also defined as the caring, individualized attention the firm provides to its customers.

e. Tangibles: It refers to a service's look or feel. They are defined as the appearance of physical facilities, equipment, personnel and communication materials. All of these provide physical representations of images of the service that customers, particularly new customers, will use to evaluate quality (Parasuraman, Zeithaml \& Berry, 1988).

\section{Methodology}

In this study, descriptive research design has been used. This study is mainly based on primary data. Primary sources of data have been collected through structured 
and unstructured questionnaire and in-depth interview with employees of different department. The study has been conducted by suing survey methodology to deal with level of customer satisfaction in the context of Nepalese commercial banks. There are all together 28 commercial banks operating in Nepal till fiscal year 2016/17. These banks are the population of the study. Out of them, Prabhu Bank Ltd., Nepal Investment Bank Ltd., Himalayan Bank and Everest Bank Ltd. are considered as sample unit using convenience sampling method. For the survey 100 questionnaires were randomly distributed to 25 customers of each sampled bank. Out of 100, only 65 usable questionnaires were returned for a response rate of 65 percent. Out of them 15 respondents were loan taker and remaining 50 respondents were account holder. For the industry and company analysis, secondary data have been used. The secondary sources of data are annual report of banks and NRB, brochures, web pages, books, business publication and government publication.

Conbach's alpha was used to test the reliability. The results of Cornbach's alpha value were compared to the published estimates (Nunnaly's 0.70) for pre-existing scales used in the study. The calculated value is 0.75 which is greater than the published estimate of Nunnaly. It strongly describes internal consistency estimate of reliability of summated scale. Thus, it is claimed that the instruments used in this research is reliable enough.

\section{Empirical Findings and Analysis}

This section deals with the some of the empirical findings and analysis based on collected data.

\section{Reliability Dimension}

The target respondents were asked two questions to measure the views on the reliability factor in services of commercial banks for analyzing the customer satisfaction. For analyzing the customer satisfaction, the respondents were asked 'when you have a problem, banks show a sincere interest in solving it'. The detail analysis of the respondents is shown in the table and figure as below:

Table 1: Sincere interest in solving customer's problems

\begin{tabular}{lccc}
\hline Category & Number of Respondents & Percentage & Cumulative percentage \\
\hline A (Strongly agree) & 10 & 15.38 & 15.38 \\
B(Agree) & 39 & 60.00 & 75.38 \\
C (Disagree) & 14 & 21.54 & 96.92 \\
D (Strongly disagree) & 2 & 3.08 & 100 \\
\hline Total & 65 & 100 &
\end{tabular}

The analysis reveals that 60 percent of total respondents (i.e. 39 respondents) are agreed and 15.38 percent of total respondents (i.e. 10 respondents) are strongly agree with the statement while less than 10 percentage respondents strongly disagree on the statement which works on bank's favour. They indicate that the sincere interest in solving the problems of customers while only few respondents strongly disagree on the statement. So this statement reveals that the banks' customers are satisfied with 
the service provided by the banks in solving the customers' problems.

Similarly the respondents were asked 'When bank promises to do something by certain time, it does so'. The detail analysis of the respondents is shown in the table and figure as below:

Table 2: Fulfillment of the promises

\begin{tabular}{lccc}
\hline Category & Number of Respondents & Percentage & Cumulative percentage \\
\hline A (Strongly agree) & 11 & 16.92 & 16.92 \\
B(Agree) & 36 & 55.38 & 72.3 \\
C (Disagree) & 17 & 26.15 & 98.45 \\
D (Strongly disagree) & 1 & 1.55 & 100 \\
\hline Total & 65 & 100 & \\
\hline
\end{tabular}

The analysis shows that 11 respondents (i.e. 16.92 percent) strongly agree and 36 respondents (i.e. 55.38 percent) agree that the banks fulfils it promises while only 17 respondents (i.e. 26.15 percent) disagree and 1 respondent (i.e. 1.55 percent) strongly disagree with the statement which is basically good for banks as more satisfied customers means more good performance for the banks. Still, some dissatisfied customers can still be satisfied though delivering promises by time.

\section{Responsiveness Dimension}

While measuring the customer satisfaction the customer satisfaction on the basis of service quality, the target respondents were asked three questions to measure the views on the reliability factor as a second dimension. For analyzing the customer satisfaction, the respondents were asked 'Services, given by bank are fast and efficient.' The detail analysis of the respondents is shown in the table and figure as below:

Table 3: Fast and efficient services

\begin{tabular}{lccc}
\hline Category & Number of Respondents & Percentage & Cumulative percentage \\
\hline A (Strongly agree) & 8 & 12.30 & 12.30 \\
B(Agree) & 27 & 41.54 & 53.84 \\
C (Disagree) & 28 & 43.08 & 96.92 \\
D (Strongly disagree) & 2 & 3.08 & 100 \\
\hline
\end{tabular}

Total $65 \quad 100$

As the study shows that 12.3 percent strongly agree and 41.54 percent of the respondents agree with the statement. 43.08 and 3.08 percent of the total respondents disagree and strongly disagree with the statement respectively. So, mixed answers are found in this statement. The bank needs to know why some of the customers are not finding its services fast and efficient and work to improve it.

Similarly the respondents were asked 'Bank inform you about its various existing and new services'. The detail analysis of the respondents is shown in the table and figure as below: 
Table 4: Bank informs about its existing and new services/products

\begin{tabular}{lccc}
\hline \multicolumn{1}{c}{ Category } & Number of Respondents & Percentage & Cumulative percentage \\
\hline A (Strongly agree) & 2 & 3.08 & 3.08 \\
B(Agree) & 32 & 49.23 & 52.31 \\
C (Disagree) & 16 & 24.62 & 76.93 \\
D (Strongly disagree) & 15 & 23.07 & 100 \\
\hline Total & 65 & 100 & \\
\hline
\end{tabular}

As the study shows 24.62 percent of the customers don't know about different existing services. Therefore, looking at the result, the bank should maintain regular follow up with their customers and update them with various upcoming schemes; only if the customers are informed about the new services they will be able to increase deposit. But 49.23 percent of the respondents get information about the services of bank. 23.07 percent of the respondents strongly disagree with the statement and 3.08 of the respondents strongly agree with the statement.

Similarly the respondents were asked 'Employees of bank always doing supportive action towards customers'. The detail analysis of the respondents is shown in the table and figure as below:

Table 5: Supportive action towards customers

\begin{tabular}{lccc}
\hline \multicolumn{1}{c}{ Category } & Number of respondents & Percentage & Cumulative Percentage \\
\hline A (Strongly agree) & 8 & 12.31 & 12.31 \\
B(Agree) & 42 & 64.62 & 76.93 \\
C (Disagree) & 15 & 23.07 & 100 \\
D (Strongly disagree) & 0 & 0 & 100 \\
\hline Total & 65 & 100 &
\end{tabular}

It shows that, 64.62 percent of the respondents are somewhat satisfied whereas 12.31 percent of the respondents are strongly satisfied with the statement that employees of the bank are always doing supportive action towards customers. No percent of the respondents strongly disagree with the statement and 23.07 percentages of the respondents disagree with the statement. So, customer satisfaction level is high regarding employees doing supportive actions towards customers.

\section{Assurance Dimension}

Two questions were provided to the target respondents to measure the customer satisfaction on assurance factor in services of Nepalese commercial banks. The respondents were asked "whether staff behaviour of the bank towards customers is excellent or not." The detail analysis of the respondents is shown in the table and figure as below:

Table 6: Behaviour of the staffs

\begin{tabular}{lccc}
\hline \multicolumn{1}{c}{ Category } & Number of Respondents & Percentage & Cumulative Percentage \\
\hline A (Strongly agree) & 16 & 24.62 & 24.62 \\
B(Agree) & 42 & 64.61 & 89.23
\end{tabular}




\begin{tabular}{lccc}
\hline \multicolumn{1}{c}{ Category } & Number of Respondents & Percentage & Cumulative Percentage \\
\hline C (Disagree) & 7 & 10.77 & 100 \\
$\begin{array}{l}\text { D (Strongly } \\
\text { disagree) }\end{array}$ & 0 & 0 & 100 \\
\hline Total & 65 & 100 & \\
\hline
\end{tabular}

Here, 24.62 percent strongly agree and 64.61 percent agree about the bank's staff is well trained, friendly and have positive attitude. And nobody strongly disagrees with the statement. But still there is 10.77 percent of customers who still feel that the banks' staffs require training on their communication skills. But basically, customer satisfaction on staff behaviour of the bank is pretty good.

Similarly in response to the statement 'it is safe to deposit money at bank', the detail analysis of the respondents is shown in the table and figure as below:

Table 7: Safe to deposit the money

\begin{tabular}{lccc}
\hline Category & Number of Respondents & Percentage & Cumulative Percentage \\
\hline A (Strongly agree) & 43 & 66.15 & 66.15 \\
B(Agree) & 21 & 32.31 & 98.46 \\
C (Disagree) & 1 & 1.54 & 100 \\
D (Strongly disagree) & 0 & 0 & 100 \\
\hline Total & 65 & 100 &
\end{tabular}

Here, the result seems very fruitful because 66.15 percent of the customers strongly agree and 32.31 percent of the customers agree that there is safe to deposit money at the banks whereas only 1.54 percent of the customers are dissatisfied with the statement. And none of the respondents were strongly dissatisfied. So, basically most of the customers of the commercial banks think that it is very safe for them to deposit their money in it.

\section{Empathy Dimension}

The target respondents were provided with three questions to measure their views on the empathy dimensions in the service provided by the banks for analyzing the customer satisfaction. The respondents were asked 'To what extent do you think the staffs of the bank understand your problems and queries.' The detail analysis of the respondents is shown in the table and figure as below:

Table 8: Staffs understand your problem

\begin{tabular}{lccc}
\hline \multicolumn{1}{c}{ Category } & Number of Respondents & Percentage & Cumulative Percentages \\
\hline A (Strongly agree) & 27 & 41.54 & 41.54 \\
B(Agree) & 32 & 49.23 & 90.77 \\
C (Disagree) & 6 & 9.23 & 100 \\
D (Strongly disagree) & 0 & 0 & 100 \\
\hline Total & 65 & 100 & \\
\hline
\end{tabular}

As the study shows that 41.54 percent of the customers strongly think that the staffs of the bank always understands the problem and queries as well as 49.23 percent of customers have reported that the staff sometime understands the problem 
and queries. However, 9.23 percent of the respondents have not found the staffs of the bank understand the problems. None of the respondents strongly disagreed with the statement though.

\section{Tangibles}

The target respondents were provided with a question to measure their views on the tangibles in the service provided by the commercial banks for analyzing the customer satisfaction. The respondents were asked 'The appearance of physical facilities, equipment, personnel and communication materials are very well.' The detail analysis of the respondents is shown in the table as below:

Table 9: The appearance of physical facilities, equipment, personnel and communication materials

\begin{tabular}{lccc}
\hline \multicolumn{1}{c}{ Category } & Number of Respondents & Percentage & Cumulative Percentages \\
\hline A (Strongly agree) & 15 & 23.08 & 23.08 \\
B (Agree) & 32 & 49.23 & 72.31 \\
C (Disagree) & 10 & 15.38 & 87.69 \\
D (Strongly disagree) & 8 & 12.31 & 100 \\
\hline
\end{tabular}

Total $65 \quad 100$

Here, the study shows that only 27.69 percent of total respondents disagree with the statement and 72.31 percent respondents agree with the statement. So, the result is positive.

\section{Customer Satisfaction}

The 4-points Likert-Like scale was classified in this study in strongly agree band (with mean score $>3.00$ ), agree (with mean score $2.01-3$.) and disagree band (with mean score $1.01-2$ ), and strongly disagree band (with mean score $\leq 1$ ).

Table: 10 Satisfaction factors

\begin{tabular}{lll}
\hline & Mean & $\begin{array}{l}\text { Standard } \\
\text { Deviation }\end{array}$ \\
\hline When there is problem, bank shows a sincere interest in solving. & 2.88 & 0.65 \\
When bank promises to do something by a certain time, it does so. & 2.88 & 0.59 \\
Services given by bank are fast and efficient & 2.63 & 0.45 \\
Bank inform you about its various existing and new services & 2.32 & 0.87 \\
$\begin{array}{l}\text { Employees of banks always doing supportive action towards } \\
\text { customers }\end{array}$ & 2.89 & 0.67 \\
$\begin{array}{l}\text { Whether staff behaviour of the commercial banks towards } \\
\text { customers is excellent or not }\end{array}$ & 3.03 & 0.64 \\
$\begin{array}{l}\text { It is safe to deposit money at the bank } \\
\text { To what extent do you think the staffs of the bank understand your } \\
\text { problems and queries }\end{array}$ & 3.65 & 0.27 \\
$\begin{array}{l}\text { The appearance of physical facilities, equipment, personnel and } \\
\text { communication materials are very well }\end{array}$ & 3 & 0.49
\end{tabular}

The mean value of respondents ranged from 2.32 to 3.65. No factors mean values scores fall into the strongly disagree $(<1)$ category. Overall mean value of respondents is 2.94. Meanwhile, the standard deviation for these variables is less than 1.00 . 


\section{Discussion and Conclusion}

This study is mainly focused at finding the level of customer satisfaction regarding service quality of commercial banks in Nepal regarding service quality with the help of five different dimensions. The major findings on the basis of variables presented can be summarizing as follows:

- The target respondents were asked two questions to measure the view on the reliability dimension. Regarding sincere interest in solving the problem, about $75 \%$ of customers believe the bank shows a sincere interest in solving any type of problem. About delivering on promises, customers above $70 \%$ believe that the bank has the ability to perform the promised service in accurate and fixed time. So both questions have got lower portion of disagreement.

- Regarding to the responsiveness dimension, i.e. the services of the bank are fast and efficient, 53\%respondents are agreed with the statement but still $47 \%$ of respondents think that they do not get satisfactory fast services in the banks. Customers, who think that the employees in the bank are always doing supportive action towards them, are about $75 \%$. But $25 \%$ of the respondents are not satisfied with the same.

- About the bank informs its existing services or products, participants only about $3 \%$ think that they are personally informed by the bank. However, participants about $50 \%$ think that they are not informed by the banks. But around $47 \%$ participants get information from the advertisement of the bank.

- Most of the customers are satisfied with the behavior of the staff of the banks. At the same time, less than $12 \%$ people do not feel the same.

- About $98 \%$ customers think that it is safe to deposit the money at the banks. It means large portion of customers feel safety. However, a negligible portion of people do not believe the same.

- According to the empathy dimension, customers around 50\% think the level of individual attention given by the bank is satisfactory but about the other $50 \%$ of people are disagreed on it.

- Regarding the staffs understand the problem and queries of the customers, for about $90 \%$ customers think that the employees of the banks are able to understand the problems. But less than $10 \%$ of the respondents completely disagree with the statement.

- About bank's location, customers above $70 \%$ think that the location of the banks is convenient and easy to get it. On the contrary, regarding the bank's ATM counters, large pool of customers show disagreement. More than $50 \%$ of customers think that the commercial banks should add more ATM counters in appropriate places.

- Only about $40 \%$ of the customers say that staffs of the banks help them to fill up the deposit slip, check and other forms. Rest of $60 \%$ of the customers disagrees with the statement.

- More than $75 \%$ participants think that the banks have modern equipment and technology whereas rests of the customers don't think same.

- Large portion of customers think that the physical facility provided by the 
banks is well sufficient. Only $27.69 \%$ customers feel not well regarding tangibles facilities.

- The mean value of respondents ranged from 2.32 to 3.65 and overall mean value of respondents is 2.94 .

From the study, it is concluded that out of fifteen questions, except staffs of the banks giving assistance to fill up the deposit slip, check and other forms and adequate parking space, all the statement got positive results. Hence the level of customer satisfaction of the banks on the basis of service quality can be considered satisfactory. The target respondent were asked two questions to measure the views on the reliability dimension i.e. showing sincere interest in solving the problem and fulfillment of promises in accurate time. Both questions have got higher portion of agreement. Among three questions under responsiveness, majority portion of customers agree with employees doing supportive action towards customers. However, about half of the customers aren't informed about different existing services of the banks. And also do not really feel the services given by the commercial banks are fast and efficient.

In regarding to assurance dimension, two questions were asked i.e. behavior of the staff and safe to deposit in the bank. Large pool of respondents is agreed on both. Among three questions under empathy, more than half of the customers disagree with the banks' staffs give assistance to fill up the deposit slip, cheque and other forms. But large portion of customer's agree that staffs of the banks understand their problems and queries well though some of them still think individual attention given to them can improve.

Under the tangible dimension, majority of customers have given agreement statement i.e. convenient location of banks, availability of modern technology, availability of waiting area and rest room. In contrast, majority of customers have given disagreement on adequate availability of the parking space. And some customers still feel location of ATM counters need to be appropriate and convenient. These all show the customers are satisfied with service quality of Nepalese commercial banks. However, the banks need to improve their service quality in future to anticipate challenges.

\section{Limitations and Direction for Further Research}

This study is carried out within the branches of selected banks. That's why the findings of this study may not be applicable for all places and situations. Thus, further research can be conducted taking the different place into consideration. Second, the study has not attempted to examine the effect of customer satisfaction on the performance of banks. So, further research can be conducted taking them into consideration. Third, the study is based on data available from the self administered questionnaire method among the customers of the banks. Findings of the study may vary over time because of change in the behavior of the people.

\section{References}

Anderson, E.W. \& Sullivan. S. (1993). The antecedents and consequences of consumer satisfaction for firms. Marketing science,Vol.12. 
Bitran, G. \& Lojo, M. (1993). A framework for analyzing the quality of the customer interface. European Management Journal, 11(4), 385- 396.

Cronin, J.J. Jr \& Taylor, S.A. (1992). Measuring service quality: a re-examination and extension. Journal of Marketing, Vol. 56, pp. 55-68.

Faizan, M., et al. (2011). Impact of customer satisfaction on customer loyalty and intentions to switch: Evidence from Banking Sector of Pakistan. International Journal of Business and Social Science, Vol. 2 No. 16.

Fornell, C. (1992). A national customer satisfaction barometer: The Swedish Experience. Journal of Marketing, Vol. 56.

Gronroos, C. (2001). The perceived service quality concept - a mistake?. Managing Service Quality, Vol. 11 No. 3, pp. 150-2.

Gronroos, C. (1990). Service management and marketing , Lexington Books, Lexington, MA.

Gronoos, C. (1984). A service quality model and its marketing implications. Journal of the Academy of Marketing Science, Vol. 24.

Gronroos, C. (1982). Strategic management and marketing in service sector. Marketing Science Institute, Cambridge, MA.

Hull, L. (2002). Foreign-owned banks: Implications for New Zealand's financial stability. Discussion Paper Series, DP2002/05.

Ioanna, P. D. (2002). The role of employee development in customer relations: The Case of UK Retail Banks. Corporate Communication, 7(1), pp. 62-77.

Jamal, A., \& Naser, K. (2002). Customer satisfaction and retail banking: an assessment of some of the key antecedents of customer satisfaction in retail banking. International Journal of Bank Marketing 20 (4), 146-160.

Kaynak, E. \& Kucukemiroglu, O. (1992). Bank and Product Selection: Hong Kong. The International Journal of Bank Marketing, 10(1), pp. 3-17.

Kotler, P. \& Keller, K.L. (2012). Marketing management. New Delhi: Dorling Kindersley (India) Pvt. Ltd.

Leeds, B. (1992). 'Mystery shopping' offers clues to quality service. Bank Marketing, 24(11), November, pp. 24-27.

Levesque, T. \& G.H.G. McDougall (1996). Determinants of customer satisfaction in retail banking. International Journal of Bank Marketing 7, 12-20.

Lewis, R. C. \& Booms, B. H. (1983). The marketing aspects of service quality. In L. L. Berry, G. L. Shostack, \& G. D. Upah (Eds.), Emerging perspectives in services marketing (pp. 99- 107). Chicago, IL: American Marketing Association.

McDougall, H.G. \& T.J. Levesque (1994). Benefit segmentation using service quality dimensions: an investigation in retail banking. International Journal of Bank Marketing 2, 15-23.

Nunnally, J.C. (1978). Psychometric theory. New York: McGraw-Hill.

Parasuraman, A., Zeithaml, V. A., \& Berry, L. L. (1988). SERVQUAL: A multiple-item scale for measuring consumer perceptions of service quality. Journal of Retailing, 64(1), 12- 40.

Parasuraman, A., Zeithaml, V.A. \& Berry, L.L. (1985). A conceptual model of service quality and its implications for future research. Journal of Marketing, Vol. 49, pp. 41-50.

Storbacka, K., Strandvik, R \& Gronroos, C. (1994). Managing customer relationship for profit: the dynamics of relationship quality. International Journal of Service Industry Management, 5(5), pp. 21-38. 
Zairi, M. (2000). Managing customer dissatisfaction through effective complaint management systems. The TQM Magazine, 12 (5), 331-335.

Zikmund, W. G. (2007). Business research methods. New Delhi: Thomson South-Western. 